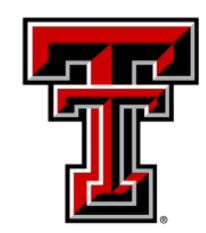

TEXAS TECH UNIVERSITY

Libraries"

\title{
Making ANd BREAKIng PARTY LeAdeRs? An InformationAL TheORY OF TEMPORARY AND LASTINg IMPACTS Of PRIME MINISTER DebateS IN SPAIN
}

\section{The Texas Tech community has made this publication openly available. Please share how this access benefits you. Your story matters to us.}

\begin{tabular}{|l|l|}
\hline Citation & $\begin{array}{l}\text { Sagarzazu, I., \& Williams, L. K. (2017). Making and Breaking Party } \\
\text { Leaders? An Informational Theory of Temporary and Lasting } \\
\text { Impacts of Prime Minister Debates in Spain. Social Science } \\
\text { Quarterly, 98(3), 856-875. https://doi.org/10.1111/ssqu.12446 }\end{array}$ \\
\hline Citable Link & $\underline{\text { http://hdl.handle.net/2346/73345 }}$ \\
\hline Terms of Use & $\underline{\text { CC-BY }}$ \\
\hline
\end{tabular}




\title{
Making and Breaking Party Leaders? An Informational Theory of Temporary and Lasting Impacts of Prime Minister Debates in Spain*
}

\author{
Inaki Sagarzazu \\ Texas Tech University \\ inaki.sagarzazu@ttu.edu \\ Laron K. Williams \\ University of Missouri \\ williamslaro@missouri.edu
}

\footnotetext{
*A previous version of this project were presented at the "The New World of Comparative Political Communication Conference," Texas A\&M University, 2016. We would like to thank the conference participants and Guy D. Whitten for their extremely helpful comments. Direct all correspondence to Laron K. Williams at williamslaro@missouri.edu.
} 


\begin{abstract}
:
Objective: In this paper we develop an informational theory that identifies the debates that will be most meaningful in terms of shifting public opinion. We argue that debates immediately following the installation of new leaders (because they shine light on leadership traits), and debates occurring in times of crisis (because voters can judge both the leader's ability to remedy the problems and their policy proposals) will have the largest short- and long-term effects.

Methods: We find support for our expectations by examining the effects of 15 Spanish State of the Nation debates from 1998-2016 on vote intention for Partido Popular (PP) and the Partido Socialista Obrero Espanol (PSOE).

Results: Debates following the installation of new party leaders can produce sizable improvements in vote intention, but the most meaningful debates occur during economic crises.

Discussion: Parliamentary debates are valuable opportunities for party leaders to shift public opinion in their favor, a fact that is not lost to them considering the time and energy devoted to crafting strategies, and the media's fascination with providing extensive coverage of the debates. This study has important implications for the study of dynamic processes (such as vote intention), and the link between parties' strategic communications and voting behavior.
\end{abstract}




\section{Introduction}

To what extent can executives sway public opinion via their performance in parliamentary debates? If so, can leaders meaningfully influence citizens' evaluations of them in the long-term? In his now classic book Going Public Samuel Kernell argues that U.S. Presidents use the power of the bully pulpit to rally public opinion and get their agendas passed (Kernell 1986). In contrast, Edwards (2003) argues that Presidents simply do not have this ability to move public opinion at will. These two authors in a way represent the extremes of the scholarly debate on the effect of presidential addresses on public opinion. However, they are not the only one, see for instance Cohen (1995; see also Whitford and Yates 2009; Tedin 2010). Speeches in the US (such as the State of the Union) are one-sided events and as such more or less monopolize media and public attention 1 As such while these speeches are good to evaluate trends of attention to the chief executive's policies, or to her popularity, they provide an incomplete setting in which to understand broader institutional dynamics. From a party competition perspective, these speeches are certainly less interesting because they neglect the strategy chosen by the other side. Current research typically shows that public opinion shifts related to speeches and debates tends to be quick and short-lived (see, for example, Cavari 2013), which casts doubt on the likelihood of speeches producing meaningful, long-term change in public opinion.

To evaluate whether exchanges between party leaders have lasting effects on public opinion, we examine Spanish State of the Nation debates. The 'Debate sobre el estado de la Nacion' is a parliamentary procedure requested by the government and has been held every non-election year since 1983 (with three debates every four-year legislative term). In this debate the Prime Minister-as the representative of the Spanish government—reports on the past year's political situation. After the initial presentation by the Prime Minister there is a round of exchanges between the Prime Minister and the leaders of the different party groups, whereby each party group receives an amount of time proportional to its size in the chamber. The most important interactions, and those with the most extensive media coverage, are those between the Prime Minister and the Leader of the Opposition (alternating between the Partido Popular, or PP, and the Partido Socialista Obrero Español, or PSOE).

Whether it is speeches or debates, however, the strategic objectives behind these communications tend to be similar. On one hand, these debates provide the opportunity to improve public perceptions of the party leader, and on the other hand, the leader can shift around issues on the public's agenda. As we mentioned above, these objectives are easier to meet if there is only one speaker (such as a speech). In either case these two strategies have been linked together in the literature as we have found (not without disagreements) that issue attention by politicians is directly

\footnotetext{
${ }^{1}$ A slight exception is the US State of the Union in the sense that the opposition party does give a speech, however, this speech is less a debate and more a simple rebuttal of the Presidential address.
} 
linked to the way people evaluate leaders and governments and can very well determine electoral outcomes (see for instance Petrocik 1996; Ansolabehere and Iyengar 1994; Williams, Seki and Whitten 2016; Pardos-Prado and Sagarzazu forthcoming). The strategic nature makes these debates that much more informative for analyzing the effects of political communication.

Analyzing the impacts of these executive debates matters a great deal from the standpoint of democratic representation, and therefore deserves more attention than it has received. First, Spanish debates represent an accurate and visible reflection of parties' strategies. Politicians devote a meaningful amount of time to preparing for debates and carefully contructing arguments. Their conflictive nature attracts more attention than speeches, so the Spanish debates are well-publicized by media (Quintero 2013). Moreover, partly because they form the basis for future issues of contention between the parties, they attract a great deal of attention, as post-debate surveys typically show that $75 \%$ of the population is aware of the debate (Centro de Investigaciones Sociologicas). Second, the debates provide opportunities to reveal leadership qualities that are closely connected to quality governing, and also give party leaders an unfiltered channel by which they can communicate positions, platforms, and actionable policies to address salient issues. It is therefore worthwhile to determine whether these debates influence voters' considerations. If voters do not respond to these debates it would reveal, at a minimum, that they are missing out on an invaluable opportunity to incorporate valence attributes and policy positions into their electoral choices. At worst, it would provide yet another piece of evidence in favor of an increasingly pessimistic view of citizen knowledge in democratic states (e.g., Neuman 1986). A bigger consequence arises if political knowledge is related to higher turnout and better evaluations of candidates (e.g., Delli Carpini and Keeter 1996; Verba, Schlozman and Brady 1995; Palfrey and Poole 1987), then over time there will grow to be a gap in political representation between those who are more and less attentive to debates.

Prominent theories of politics have long disagreed over the most successful strategies for influencing public opinion through campaign messages and debates such as these. Party leaders and the head of government have two strategies for these debates in terms of what they communicate to the public. On the one hand they could thread a speech in which they touch upon the issues their party "owns" (Petrocik 1996) and how the government/opposition has not paid attention to it. Alternatively they could hammer the government/opposition on the most salient issue to the public, trying to appear the most responsive actor to citizen's concerns. In simple terms, the issue ownership literature argues that political parties are associated with certain issues that they are better at handling (vis-à-vis other parties) (Budge and Farlie 1983).

This ownership tends to come from two sources. The first source is long associations in the constituencies within the electorate: for instance, center-left parties' association with unions, social movements, and the expansion of rights 
and center-right parties' association with law and order, defense, or religious organizations. These associations give credence to center-left parties ownership of social issues and center-right parties ownership of law-and-order and defense issues. A second form of ownership comes from what Petrocik (1996) terms performance issues. This type is more temporal and depends on the job of a political party in handling a given issue, for instance corruption/transparency. Depending on the political context, the economy moves from a traditional long-term issue to a performance issue. In the end however, it is the citizens—as a group—who decide which party owns which issue. The main consequence of the existence of issue ownership for political communication as it relates electoral politics, is that if a party owns an issue it should strive to put and keep that issue on the political agenda. Voters who are dissatisfied with performance on an issue will choose to support the party deemed most capable at improving the issue, or alternatively, the party that "owns" the issue.

The second theory arises from parties' incentives to be responsive to the electorate. Instead of parties emphasizing their owned issues (as issue ownership theory suggests), their campaign messages should instead focus on the most important problem regardless of who owns it (Ansolabehere and Iyengar 1994). By doing so parties show the electorate they are listening to their concerns and willing to offer solutions to the problems considered to be most salient. Failing to offer viable solutions to the most salient problems risks face backlash from a dissatisfied electorate. The strategy of addressing the most salient issue is not without risk, however. The strategy may backfire for the issue's non-owner as it will highlight an issue in which they are not perceived as the more capable party (Vavreck 2009).

We develop a theory that those debates that offer the greatest amount of new information-either in terms of revealing personal characteristics of leaders or their proposed positions-will be most impactful. We derive two empirical expectations related to the role of information. First, the debates immediately following the installation of new leaders are ripe settings for revealing information to voters, and as such, offer the best chance for leaders in all parties to compete for voters' support. The second expectation is a unique contribution to the field of political communication by integrating the research on issue salience and ownership (see above). Though the optimum strategies pursued by parties is a point of contention, both theories identify certain debates in this time period as being most meaningful. These debates occur during the economic crisis, and are meaningful because they tap into perceptions of ownership of economic policy by PP and a clear instance of poor economic performance by the incumbent PSOE on the most pressing problem.

We test our expectations using a data set of quarterly vote intention in Spain from 1998q3 to 2016q2, a period covering 15 State of the Nation debates across five cabinets and two mainstream parties overseeing single-party majority governments. Results for seemingly unrelated regression (SUR) models provide limit support for our first expectation 
and much stronger support for the second. To summarize, we find that parties with new leaders benefit from the first debate in limited circumstances (Pedro Sanchez's first debate as leader of PSOE in 2015), but much stronger punitive effects occur during PSOE's tenure overseeing the economic crisis. In this period, PP consistently gains at the expense of PSOE for reasons that we theorize are related to their poor management of the most salient problem and PP's perceived advantage in economic management. Furthermore, the dynamic nature of Spanish vote intention means that the effects of debates (and the other variables) influence vote intention in the short- and long-term. In fact, only looking for effects in the periods following debates leads one to underestimate the overall magnitude of debates on public opinion.

The remainder of the manuscript is structured as follows. In the next section we develop our expectations based on our informational theory of debate impacts. We then describe the data used, present our model specification, and discuss some obstacles related to our estimation strategy. In the fourth section, we explore the short- and long-term impacts of Spanish debates on vote intention. In the last section we conclude.

\section{Theory}

Debates provide a highly-publicized opportunity for the party leaders to elevate the importance of issues on the public's agenda, shift blame or accountability for policy failures, or offer their preferred plan for addressing the salient issues moving forward. Debates where leaders do particularly well in implementing the strategies listed above are likely to capture the attention of the public. Debate performances such as these may result in shifting issue priorities, improvements in leaders' valence characteristics (such as trustworthiness, leadership, perceptions of best manager, etc), or vote intentions. Our focus is on the characteristic that we feel is most closely linked to behavior at the polls: vote intention.

We theorize that the value of these debates in terms of shifting public opinion arises from providing information to voters. Thus, we should be able to anticipate the debates that will be the most momentous by incorporating insights from three literatures in political science. Some of these debates include those situations where there is a new party leader, because the debate offers that leader the opportunity to demonstrate the favorable valence characteristics that attract voters. Other debates are momentous in that they offer the leaders a chance to provide a path forward out of crisis (financial or otherwise). If voters are not satisfied with the plans offered by the party leaders (in particular if the party itself is perceived to be accountable for the policy failure), then they will shift their vote intention elsewhere. Based on this theory, we would expect to see that the debates that are most impactful are those that provide the greatest 
amount of information for the voters; this occurs when new party leaders are given a chance to debate, they emphasize issues that their party owns, or when there are highly salient exogenous shocks.

The effect of party leader change on voter evaluation of parties and their leaders should be significant for several reasons. On the one hand because there is an ever-closer relationship between party, party leader, and the information voters use to make choices and evaluations. For instance, extant literature in political science has found the high cost of information acquisition and the importance of simplified cues for voting behavior (see for instance Berelson 1954; Ferejohn and Kuklinski 1990; Popkin 1991; Zaller 1992; Fortunato and Stevenson 2013). On top of this, research has found that voting behavior is highly dependent on the party candidate and not just on the party label (Farrell and Webb 2000; Mughan 2000; Garzia 2012; Takens 2015). On the other hand, party leadership change implies an increase of information whether in the form of media coverage-due to the newsworthiness of the change (McQuail 1993) — or in the form of increased attacks from other parties trying to define the new leader. As friends and foes define this 'unknown leader, voters take these informational cues and form an opinion of the new leader and re-assess their view of the party (Somer-Topcu 2016; Gelman and King 1993; Barabas and Jerit 2009; Franklin 1991; Stevens and Banducci 2013). Debates reveal this information quite well. For the above reasons, we offer our first theoretical expectation:

Expectation 1: Debates following the introduction of new party leaders will be more impactful than other debates.

This time period in Spain offers a unique opportunity to assess how voters' responses to party elites' messages change as a function of shifting issue priorities. Spain experienced a recession from the third quarter of 2008 to the first quarter of 2010, though economic conditions did not immediately rebound with positive growth. The unemployment rate hovered above $20 \%$ during this time period, which contributed to the drastic shift in the public's issue priorities away from social issues and toward the economy. Figure 1 uses monthly survey data from the Spanish Barometro (described in-depth below) to determine the percentage of respondents identifying economic issues (thick solid line) and social and welfare policy issues (dashed line) as the "most important problem" (MIP) facing the country. While the most direct inference that can be drawn from these responses to the MIP question centers on the public's attention to a specific problem, other scholars have used the responses to make claims about issue importance, problem status, public concerns, and public preferences for policy (see the review in Jennings and Wlezien 2015). Regardless, the MIP measures paint a picture of the public's attention to problems that warrant government action. We also see from the bottom panel of Figure 1 that concern for the economy covaries with the public's evaluations of the national retrospective economy.

[Figure 1] about here] 
The issue salience argument would posit that both parties would increase their emphasis of economic issues (while perhaps varying the strategies offered to solve the problems) to appeal to voters. Although one party might have a supposed advantage over the other in terms of perceived economic performance, it must still address such salient pressing problems; to ignore salient problems is "to risk failing to make an appeal to new voters and to dishearten older supporters by displaying the party's irrelevance to modern developments" (Klingemann, Hofferbert and Budge 1994: 29).

With regards to ownership of the economy there are multiple reasons to believe that PP owns the issue. This link can be made on several accounts. First, in the 1999-2009 period the PP has been selected as the party most competent to handle the economy by a majority of respondents to the European Social Survey. The only exception was 2004, yet there are strong reasons to believe that the 2004 wave results were affected by the Madrid bombings. Second, research has found no relationship between economic competence and voting for the PSOE (Hamann 2000); while at the same time finding a strong relationship between the PP and economic ownership (Pardos-Prado and Sagarzazu forthcoming). Third, socialist governments are associated with poor macro-economic performance first during the democratic stabilization period of the 80's and early-90's and secondly during the post-financial crisis in the late2000's.

While the issue salience and ownership theories offer competing expectations about the strategies parties select to emphasize issues during these debates, they are consistent with respect to the impacts of debates during periods under examination here. In fact, during those debates where the incumbent PSOE is facing a monumental financial crisis, both theories point to PP being rewarded by voters. As the top panel of Figure 1 shows, the economy was clearly the most important problem to the vast majority of respondents, rising above $75 \%$ from mid-2008 through 2012 . As a single-party majority government, PSOE was clearly and solely responsible for any failed government efforts to remedy the most pressing issue facing the country.

PP also was poised to benefit from the economic situation beyond simply being the most credible governing alternative in the opposition. Issue ownership theory would suggest that voters will look to the most capable party to pull them out of recession. For both of these reasons, we have the following expectation:

Expectation 2: PP will benefit at the expense of PSOE following debates occurring during the financial crisis. 


\section{Data \& Methods}

Our theory states that the performance of Spanish party leaders in the State of the Nation debates can improve their electoral prospects. The appropriate data set for this type of analysis is one that relies on aggregated survey data. The Centro de Investigaciones Sociologicas has asked a consistent battery of questions monthly (except for August) from 1998m1 to 2016m4. Though the demographic questions (age, marital status, gender, etc) are asked every survey, the battery of political questions (including vote intention, previous vote, ideology, etc) are asked nearly quarterly (typically in January, April, July and October). Nevertheless, this long time series of quarterly data gives us plenty of variation required to test our theoretical expectations. In Figure 2 we depict the quarterly vote intention for PP and PSOE.

[Figure 2] about here]

The first pattern from Figure 2 is that the government party tends to have a higher level of vote intention than the opposition party; this is the case for the majority of Aznar's two terms in office (except for immediately prior to the 2004 election) and for PSOE (before the finanical crisis starting in 2009). It is also apparent from the first few years of Figure 2 that Spanish politics can be characterized as zero-sum; as one mainstream party gains votes, the other party loses them. This is not the case, however, after the financial crisis as a number of challenger parties arise (such as Ciudadanos and Podemos) and begin to siphon votes from both PP and PSOE. Nevertheless, there is a great deal of variation that cannot be explained by the simple ebbs and flows of governing.

Despite the high degree of variation provided by this long time series, scholars undertaking these sorts of empirical analyses must be weary of a number of methodological concerns. The first concern is non-stationarity. Both series are first-order integrated, which means that we need to make the series mean stationary before estimating our models or the results may be spurious (Granger and Newbold 1974) $2^{2}$ A second concern is with the possibility of autocorrelated disturbances, which causes considerable problems with hypothesis testing (Gujarati 2003) $3^{3}$ The disturbances that result from careful model specification (described in-depth below) can be characterized as white-noise $\left.\right|^{4}$

Figure 2 reveals another potential concern related to the presence of trends that vary in magnitude and length according to the particular cabinet. Failing to effectively model these government-specific trends, in combination with

\footnotetext{
${ }^{2}$ For both series (PP and PSOE vote intention), in both tests (Dickey-Fuller and Phillips-Perron), we fail to reject the null hypothesis of a unit root (p-values of 0.19 and 0.83 , and 0.19 and 0.69 , respectively). First-differencing both series allows us to reject the null hypothesis of a unit root at the $99.9 \%$ confidence level in both tests.

${ }^{3}$ These problems are exacerbated in the context of dynamic models (such as the one presented here) because the lagged dependent variables will be correlated with previous disturbances, which results in biased coefficients.

${ }^{4}$ For both series, the Portmanteau (Q) test indicates that we cannot reject the null hypothesis that the residuals are white noise (p-values of 0.91 and 0.60 , respectively).
} 
independent variables that vary as a function of time, would potentially risk spurious relationships. We address this concern by including government-specific trend variables that count the number of months that each government has been in office when the survey was administered. Thus, we can measure the exact amount that PP and PSOE vote intention changes as a function of the time that each cabinet has been in office; we therefore include trends for Aznar I (1998m1-2000m3), Aznar II (2000m4-2004m3), Zapatero I (2004m4-2008m3), Zapatero II (2008m4-2011m11), and Rajoy (2011m12-2016m4).

Another concern that exists in typical studies of vote intention is that the effects of the variables might vary depending on the party being analyzed. This is certainly not a new phenomenon (Zellner 1962 calls this "aggregation bias"), but only recently have scholars in economic voting began to appreciate that the determinants of public support might be quite different across parties (e.g., Whitten and Palmer 1996: 233; Williams, Stegmaier and Debus forthcoming). Estimating a single model with a single set of covariates for both the PP and PSOE risks aggregation bias if the covariates potentially have different effects for the parties 5 Our Theory section above detailed a number of reasons why we would not expect this assumption to hold, most notably the differences in the amount of information provided by the debates.

Finally, we estimate a seemingly-unrelated regression (SUR) of vote intention for PP and PSOE (Zellner 1962; Tomz, Tucker and Wittenberg 2002; Philips, Rutherford and Whitten 2016). This estimation procedure has the benefit of allowing a dependent variable that is bounded by 0 and 100 (in this case, vote intention), and is one where the errors across equations can be correlated. This latter quality is helpful because if there omitting any variables that similarly influence both parties' levels of support would lead to bias in ordinary least squares regression. Furthermore, SUR estimates separate covariates for each series (PP and PSOE), which produces a more flexible arrangement that does not make the unrealistic assumption that the effects are constant across parties.

With these concerns in mind, we estimate the following model for each party $j,(j=\mathrm{PP}, \mathrm{PSOE})$ :

$$
\Delta S_{j t}=f\left(\Delta S_{j t-1}+D_{t}+D_{t-1}+E_{t}+G_{j t}+E_{t} \times G_{j t}+T_{t}+H_{t}\right)
$$

- $\Delta S_{j t-1}$ is the change in party $j$ 's vote intention (\%) at time $t-1$ (last available survey), measured with responses to the following question: "Assuming that general elections for the Spanish parliament were held tomorrow, which party would you vote for?" We assume that there is a high level of negative autoregression in this series, as gains (losses) in vote intention are likely to be met with future losses (gains) as the series returns to its long-

\footnotetext{
${ }^{5}$ In the model we present below we can reject the null hypothesis of equal coefficients for PP and PSOE for 7 variables at the $95 \%$ confidence level (12 variables at the $90 \%$ confidence level).
} 
run equilibrium. In addition, since both series exhibit first-order integration, taking the first difference makes them stationary.

- $D_{t}$ is a three-month debate-specific dummy variable. Each debate will have its own estimated impact, with nondebate months serving as the reference category. Since there are multiple instances where we lack survey data in the month of the debate (or even the following month), $D_{t}$ is coded 1 for any of the three months following the debate for which we have data. Since we theorize that these debates have potentially long-lasting impacts on vote intention, we also include debate-specific variables lagged one time period for which we have data $\left(D_{t-1}\right)$. For example, consider the State of the Nation debate occurring in June 1999. Unfortunately, we lack vote intention data for June, but we have data for July and October. The three-month debate-specific variable $\left(D_{t}\right)$ would be coded 1 for June-August (we only have data for July), and the lagged variable $\left(D_{t-1}\right)$ has a value of 1 for the next month with available data (October).

- $E_{t}$ represents the average retrospective evaluation of the national economy. Voters are asked to evaluate the national economy ("Do you believe that the current economic situation is better, worse or equal than a year ago?"). Responses are recoded so that $1=$ better, $2=$ stay the same, and $3=$ worse so that higher values of $E_{t}$ represent an economy that is perceived as worsening, on average.

- $G_{j t}$ is a dummy variable capturing PP's control of government (1998m1-2004m3 and 2011m12-2016m4).

- $E_{t} \times G_{j t}$ measures the extent to which respondents' perceptions of the national economy influence vote intention, and how control of government increases this accountability. Based on the considerable research on economic voting (e.g., Powell and Whitten 1993; Duch and Stevenson 2008), we expect that worsening economic evaluations decreases the two parties' vote intentions when in government, but has no impact when in opposition. Formally, in the PP equation this means $E_{t}=0$ and $E_{t}+E_{t} \times G_{j t}<0$ and in the PSOE equation this means $E_{t}<0$ and $E_{t}+E_{t} \times G_{j t}=0$.

- $T_{t}$ includes five trend variables representing the tenure (in months) of Aznar I, Aznar II, Zapatero I, Zapatero II and Rajoy 6 With this specification, vote intention for both parties is allowed to vary as a function of government tenure in different ways.

- $H_{t}$ includes a number of dummy variables intended to capture exogenous shocks that are otherwise beyond the scope of our theory but still meaningful for public support. We begin by identifying a series of scandals and events that generated a high level of media attention; we then pare this list down to only those variables that are

\footnotetext{
${ }^{6}$ Model fit statistics indicate that these variables significantly outperform a variety of variables designed to capture "honeymoon" effects.
} 
statistically significant in either party's equation. In the end, we include a variable (Madrid Bombings) for the three months following the Madrid terrorist attacks (2004m3-2004m5) with the expectation that it will benefit the challenger PSOE at the expense of the incumbent PP.

In the next section we test our theoretical expectations with a SUR.

\section{Findings}

We theorized that Spanish debates offer a unique opportunity for party elites to communicate directly to voters in their efforts to alter the policy agenda, emphasize particular issues, or present strategies for addressing the salient problems. Since the impact of the debates is directly connected to how informative they are, we draw a number of theoretical expectations regarding which circumstances make debates more meaningful and for whom. We expect there to be positive boosts when a new party leader is introduced because the debate gives the leader a platform to demonstrate his positive characteristics vis-a-vis the other party's leader. Moreover, we expect that debates can also be a missed opportunity to present a path for addressing salient problems; this is especially the case given the salience of the economy during the financial crisis of 2008-2011.

In Table 1 we present the results from our seemingly unrelated regression (SUR) of the first difference in vote intention. Two sets of coefficients are presented in the table, representing the unique effects of the covariates for both $\mathrm{PP}$ and PSOE.

[Table 1] about here]

We previously (Figure 2) showed that current values of both parties' vote intentions are heavily influenced by the past. Indeed, the results in Table 1 suggest that both series are autoregressive, as both coefficients on the lagged dependent variables are statistically significant and negative (indicating a pendulum effect). When estimating a dynamic model such as this, the interpretation of the causal effects of variables is a bit more complex. In this case, the impact of debates on vote intention have both a short-term effect (represented by the coefficients for the concurrent debate dummies) and a long-term effect (due to the lagged dependent variable and the lagged debate dummies) (de Boef and Keele 2008). While complicating the interpretation slightly, this estimation strategy allows us to directly test whether State of the Nation debates have a lasting effect on public opinion. Table 2 presents the long-term effects (and 95\% confidence intervals) of a 1-unit increase in each of the covariates. 
[Table2 about here]

Our theoretical expectations are focused on the effects of debates on vote intentions. An effective way of depicting the dynamic nature of these relationships is with dynamic simulations (Williams and Whitten 2012). After establishing a simulation scenario for the control variables, scholars can "shock" the system by changing one of the values of the explanatory variables (in this case, a debate dummy) at time $t=1$, and then observing how the vote intention series changes over future time periods. These dynamic simulations are based on the estimates from Table 1 and have the appropriate measures of uncertainty (calculated via Clarify, see King, Tomz and Wittenberg 2000). Figure 3 shows how the influence of a debate at time $t=1$ reverberates for five time periods into the future as a result of the lagged values of the debate variables and the autoregressive nature of PP (top panel) and PSOE (bottom panel).

[Figure 3 about here]

Dynamic simulations are useful in this application because they help us make two inferences that directly test our theoretical expectations. First, we can determine whether the debate had a statistical impact on that party's vote intentions by observing whether the predicted changes are statistically different from zero (whether the $90 \%$ confidence intervals overlap 0). These impacts can occur at any of the five time periods (occurring beyond a year after the debates), but the largest impacts are clustered in the first three time periods. The dynamic simulations of PP's vote intention indicate that it often takes a couple of months for the effects of the debates to be felt; while there are three debates that had an immediate impact on vote intention (2007, 2010 and 2014, all positive), a number of other debates induce boosts in approval in the second time period $(2005,2009,2011,2013-2015)$. In each of those cases, the effect in the third time period (when the lagged value of the debate dummy has no effect) is a statistically significant drop in vote intention toward the pre-shock value.

The second inference to be gleaned from dynamic simulations is that we can determine whether one party benefited to a greater extent than the other party by comparing the confidence intervals across PP and PSOE. When the debates influence public support for PP, they tend to do so in meaningful positive ways. The largest statistically significant effects are in the first and second time periods following the debate in 2014. On the other hand, PSOE's debate effects are much more variable, with some debates boosting public support (most notably 2015), with other debates costing them dearly (2009-2013). Table 2 shows that the PP, at worst, does not gain from the debates and at best, clearly benefits (the long-term effect (LTE) are statistically significant and positive in 2003, 2009-2010, 2013-2014). The PSOE, on the other hand, only gains support in one case (2015) and clearly loses support at each opportunity from 2009-2013. 
In addition to examining whether the overall long-term effects are statistically different from each other (shown in Table 1), we can examine whether the effects are different at each of the five time periods. Recall that the null hypothesis test that the debates do not favor one party over the other would imply that there is no statistical difference at any of the time periods. Of the 70 possible tests (14 debates by five time periods), we can reject the null hypothesis of no difference between the debate's effects 38 times (54.3\%) at the 90\% confidence level (33 times at the $95 \%$ confidence level). It is clear from these dynamic simulations that the debates are meaningful drivers of vote intention and are valuable opportunities for one party to gain at the expense of the other. In fact, debates are influential more often than they are not.

Since we have demonstrated that the State of the Nation debates influence vote intention in meaningful ways, the next step is to try to explain the variation depicted in Figure 3 The first possible explanation in the variance in debate effects is due to the introduction of a new party leader. Since these debates provide information about the characteristics of leaders and the parties' platforms, we might expect larger changes (either positive or negative) for the first debates of new leaders. The results in Table 1 and Figure 3 provide mixed support for this expectation. Of the three party leaders who were installed during this time period—Jose Luis Rodriguez Zapatero's first debate as leader of the PSOE was in 2001, Mariano Rajoy's first debate as leader of PP was in 2004, and Pedro Sanchez's first debate as leader of PSOE was in 2015-only Sanchez experiences a statistically significant change. While this is the only debate that party leader effects were meaningful, it is also anomalous for the PSOE because it represents the only debate with a net gain over time (a LTE of 9.35). In this case, the PSOE clearly benefited from having a new leader.

Figure 3 provides support for our second theoretical expectation. Indeed, the second clear pattern that emerges is a stinging rejection of the PSOE's plan for economic governance. The debates in 2009-2011 occurred during a harsh economic depression where PSOE was in control of a single-party majority government. It was also clear at this time that evaluations of the national economy were quite poor (see Figure 11). The PSOE could have used this opportunity to convince the public that its economic policies were the best chance at steering the ship to calmer waters; instead, voters overwhelmingly rejected these claims and shifted their support away from the government. In fact, of the four largest predicted differences in debate effects depicted in Figure 3, three were during the financial crisis $\left(2009_{2}, 2010_{1}\right.$, and 2011 $)$. In each of these three examples, the incumbent PSOE loses a statistically significant amount (-6.9, -5.2 and $-12.6 \%)$ while the challenger PP gains a statistically significant amount (3.7, 2.8, and 4.3\%). Voters clearly rejected the strategies proposed by the PSOE to address the financial crisis, even after controlling for their perceptions of the current economy. The PP-which acted as both the most credible governing alternative in the opposition and the party that owned the economy—clearly benefited from this backlash. 
We argue that these debate effects are large and substantively impressive. This is because it is entirely reasonable to not expect any sort of effect (especially in the long-term) from these debates. For a variety of reasons, our research design and model specification are constructed to make it difficult to find any statistically significant debate effects. The largest obstacle is that we have quarterly vote intention data (at best), where the first available data is often three months following a debate. Since we do not have access to public opinion data immediately following the debate we cannot observe any sort of short-term rally which is the most likely kind of effects. Any boost that we observe often takes place months following the debate. For example, consider the debate occurring on February 24, 2015; PSOE experiences both a short-term boost $(5.77 \%)$ and a long-term boost $(9.35 \%)$. Because of the quarterly nature of these time series, the short-term effect is observed over a month later (the fieldwork for the April survey is from 1-12) and the lagged effect (2005 Debate $t_{-1}$ ) is observed over four months later (July 1-9). These are not simply blips that quickly dissipate but instead semi-permanent changes to vote intention.

Furthermore, model fit statistics indicate that we have specified a model that does a superb job in terms of explaining changes in vote intention for PP and PSOE ( $\mathrm{R}^{2}$ of 0.73 and 0.81 , respectively). Any effect (short- or long-term) that we find for debates is after we have controlled for the previous amount of change (lagged DV), exogenous events (Madrid bombing), retrospective economic evaluations (conditioned by government status), and government-specific trends (in the form of tenure). The evidence we find in favor of debate effects is rather impressive, especially considering that so many elements of the research design cloud our ability to observe the short-term effects.

The results for the control variables help in assembling a complete picture of Spanish vote intention. Table 1 shows the profound effect that the Madrid bombings on March 11, 2004 had on vote intentions for both parties; in the short-term, PP was expected to lose $17.8 \%$ while PSOE was expeted to gain $16.7 \%$. This is not the complete story of the effects, however, because we have specified a dynamic model where the effects of covariates have lasting effects. In this case, both autoregressive coefficients are negative, which indicates that increases in the first period are immediately offset by decreases in the second period. This means that the long-term effects for the concurrent variables (excluding the debate dummies, see below) are actually smaller than the short-term effect because the series have a strong inclination to return to their pre-shock values. The autoregressive parameter for the PP equation, for example, is -0.25 , which indicates that only $25 \%$ of the long-term effects occur after the first time period. Both longterm effects are statistically different from $d 7$ and almost completely offset each other (-14.33 for PP and 14.19 for PSOE).

\footnotetext{
${ }^{7}$ For the variables that only include concurrent values, the long-term effects are calculated with the following formula: $\frac{\beta_{t}}{(1-\rho)}$, where $\beta_{t}$ is the coefficient and $\rho$ is the coefficient for the lagged dependent variable; for the debate dummies, the long-term effects are calculated with the following formula: $\frac{\beta_{t}+\beta_{t-1}}{(1-\rho)}$ (de Boef and Keele 2008: 186). The confidence intervals are derived from the percentile method using Clarify (King, Tomz and Wittenberg 2000).
} 
We also theorized that the high level of clarity of responsibility of the Spanish system would produce a strong level of electoral accountability for economic performance. Voters should be able to clearly identify who is in control of government and hold that party accountable for economic performance perceived as poor. Simply examining the short-term effects (coefficients in Table 1 p provides little support for these expectations, which shows the folly of only examining the coefficients in dynamic models such as these. The long-term effect of a 1-unit increase in the average retrospective national evaluations (i.e., toward deteriorating conditions) is negative and statistically significant for PP (but not PSOE) while in government; the marginal effect is not statistically different from zero for either party while in opposition. There appears to be a higher level of accountability for economic performance for PP than PSOE, which—when combined with the withdrawal of support for the PSOE following the debates of 2009-2013—offer a complex portrayal of accountability for economic outcomes.

Finally, we included government-specific trends to capture any idiosyncratic, time-varying elements omitted from the model that might cause different trends across governments. The long-term effects presented in Table 1 suggest that public support improves over time for the government party; indeed, the long-term effects are positive for the party in power (PP during Aznar I, II, and Rajoy, and PSOE during Zapatero I and II) and negative for the opposition party. This is a somewhat counter-intuitive finding given the evidence in favor of a honeymoon period in studies of US presidential approval (e.g., Clarke and Stewart 1994). While the vastly different contexts of the US and Spain offers one potential explanation for the differences, another explanation is that our model is fully-specified and takes into account previous changes, the influence of exogenous shocks and economic evaluations. Moreover, our model has no evidence of non-stationarity or autocorrelation, both of which can cause spurious results and invalid hypothesis tests.

\section{Conclusion}

Spanish State of the Nation debates offer party leaders the unique opportunity to pit their own personal qualities and policy positions head-to-head against other leaders in an effort to sway voters to their side. We provide evidence that suggests that the strategic efforts of mainstream Spanish parties (PP and PSOE) are worthwhile. In fact, more often than not, the debates produce statistically significant shifts (both boosts and slumps) in the vote intentions of mainstream parties. Contrary to other work on the fleeting nature of these shifts (e.g., Cavari 2013), we find that debates can influence vote intentions in substantively meaningful and statistically significant ways up to a year afterward.

We theorize that identifying which debates will be meaningful for whom depends on whether the debates offer new 
information regarding the leader's character traits (a clear opportunity for new party leaders), government performance on the most salient problem, and voters' perceptions of ownership of the salient problem. PP is able to translate debate performance into voter support much more efficiently than the PSOE. In fact, the PP gains in the first and second periods following the debate more often than not. This is consistent with our theory that the PSOE's poor performance in office, coupled with PP's widespread perceived advantage in economic affairs, placed PP in an extremely favorable position. The electoral consequences of debates for PSOE are much more variable than PP. In only one debate-the 2015 debate following the introduction of Pedro Sanchez as party leader-does the PSOE benefit statistically in the long-term.

These findings of informational effects of new leaders run in parallel with recent findings in the literature that argue that leaders still matter (Farrell and Webb 2000; Mughan 2000; Garzia 2012; Takens 2015; Somer-Topcu 2016). As we have shown, new leaders have the opportunity to change voter's perceptions of parties, especially when the party is doing particularly bad. At the same time we show that long held theories of political communication which tie parties to their electoral fortunes, such as issue ownership and issue salience, affect politics in different contexts. Together these findings highlight the importance of both parties and leaders for political communications.

A second contribution is methodological. We hope that this project shows the fruits of careful model specification, particularly in terms of taking into account the dynamic nature of party competition between mainstream parties. The SUR model provides a nice way of capturing the zero-sum nature of Spanish party competition, and the incorporation of cabinet-specific trends and lagged dependent variables ensures that we effectively model the dynamics of vote intentions for both parties. The result of these choices is that State of the Nation debates have short-term effects (typically of interest to media) and lasting effects far beyond the first quarter. Future studies could clearly benefit from approaching these methodological challenges as a theoretical exercise instead of a statistical nuisance. 


\section{References}

Ansolabehere, Stephen \& Shanto Iyengar. 1994. "Riding the Wave and Issue Ownership: The Importance of Issues in Political Advertising and News." Public Opinion Quarterly 58:335-357.

Barabas, Jason \& Jennifer Jerit. 2009. "Estimating the causal effects of media coverage on policy-specific knowledge." American Journal of Political Science 53(1):7389.

Berelson, Bernard R., Paul F. Lazarsfeld \& William N. McPhee. 1954. Voting: A Study of Opinion Formation in a Presidential Campaign. Chicago: University of Chicago Press.

Budge, Ian \& Dennis J. Farlie. 1983. Explaining and Predicting Elections: Issue Effects and Party Strategies in Twenty-Three Democracies. London: George Allen and Unwin.

Cavari, Amnon. 2013. “The Short-Term Effect of Going Public.” Political Research Quarterly 66:336-351.

Clarke, Harold D. \& Marianne C. Stewart. 1994. “Prospections, Retrospections and Rationality: The 'Bankers' Model of Presidential Approval Reconsidered.” American Journal of Political Science 38:1104-1123.

Cohen, Jeffery E. 1995. "Presidential Rhetoric and the Public Agenda." American Journal of Political Science 39(1):87-107.

deBoef, Suzanna \& Luke Keele. 2008. “Taking Time Seriously: Dynamic Regression.” American Journal of Political Science 52(1):184-200.

Delli Carpini, Michael X. \& Scott Keeter. 1996. What Americans Know About Politics and Why it Matters. New Haven: YaleUniversity Press.

Duch, Raymond M. \& Randolph T. Stevenson. 2008. Voting in Context: How Political and Economic Institutions Condition the Economic Vote. Cambridge: Cambridge University Press.

Edwards, George C. III. 2003. On Deaf Ears: The Limits of the Bully Pulpit. New Haven: Yale University Press.

Farrell, David \& Paul Webb. 2000. Political Parties as Campaign Organizations. In Parties without Partisans: Political Change in Advanced Industrial Democracies, ed. Russell Dalton \& Martin Wattenberg. Oxford University Press p. 102128.

Ferejohn, John A. \& James H. Kuklinski, eds. 1990. Information and Democratic Processes. University of Illinois Press. 
Fortunato, David \& Randolph T. Stevenson. 2013. "Perceptions of Partisan Ideologies: The Effect of Coalition Participation.” American Journal of Political Science 57(2):459-477.

Franklin, Charles H. 1991. "Eschewing Obfuscation? Campaigns and the Perception of U S Senate Incumbents." American Political Science Review 858:1193-1214.

Garzia, Diego. 2012. "Party and Leader Effects in Parliamentary Elections: Towards a Reassessment." Politics 32(3):1751185.

Gelman, Andrew \& Gary King. 1993. "Why Are American Presidential Election Campaign Polls so Variable When Votes Are so Predictable?” British Journal of Political Science 23:409-451.

Granger, C.W.J. \& P. Newbold. 1974. “Spurious Regressions in Econometrics.” Journal of Econometrics 2:111-120.

Gujarati, Damodar. 2003. Basic Econometrics. Mc-Graw Hill.

Hamann, Kerstin. 2000. "Linking policies and economic voting: Explaining reelection in the case of the spanish socialist party." Comparative Political Studies 33(8):1018-1048.

Jennings, Will \& Christopher Wlezien. 2015. "Preferences, Problems and Representation.” Political Science Research and Methods 3(3):659-681.

Kernell, Samuel. 1986. Going Public: New Strategies of Presidential Leadership. Washington, DC: CQ Press.

King, Gary, Michael Tomz \& Jason Wittenberg. 2000. "Making the Most of Statistical Analyses: Improving Interpretation and Presentation." American Journal of Political Science 44:347-361.

Klingemann, Hans-Dieter, Richard Hofferbert \& Ian Budge. 1994. Parties, Policies and Democracy. Boulder, CO: Westview Press.

McQuail, Dennis. 1993. Mass communication theory: An introduction. Sage.

Mughan, Anthony. 2000. Media and the Presidentialization of Parliamentary Elections. Palgrave.

Neuman, W. Russell. 1986. The Paradox of Mass Politics: Knowledge and Opinion in the American Electorate. Cambridge, MA: Harvard University Press.

Palfrey, Thomas R. \& Keith T. Poole. 1987. "The Relationship between Information, Ideology, and Voting Behavior.” American Journal of Political Science 31(3):511-530. 
Pardos-Prado, Sergi \& Inaki Sagarzazu. forthcoming. "The Political Conditioning of Subjective Economic Evaluations: The Role of Party Discourse.” British Journal of Political Science .

Petrocik, John R. 1996. "Issue Ownership in Presidential Elections with a 1980 Case Study." American Journal of Political Science 40(3):825-835.

Philips, Andrew Q., Amanda Rutherford \& Guy D. Whitten. 2016. "Dynamic Pie: A Strategy for Modeling Trade-Offs in Compositional Variables over Time." American Journal of Political Science 60(1):268-283.

Popkin, Samuel L. 1991. The Reasoning Voter: Communication and Persuasion in Presidential Campaigns. Chicago: University of Chicago Press.

Powell, G. Bingham \& Guy D. Whitten. 1993. "A Cross-National Analysis of Economic Voting: Taking Account of the Political Context." American Journal of Political Science 37(2):391-414.

Quintero, Francisco. 2013. Debates del estado de la nación. In Codigos Comunicativos y Docencia, ed. David Caldevilla. Vision Libros pp. 369-388.

Somer-Topcu, Zeynep. 2016. "Agree or disagree: How do party leader changes affect the distribution of voters perceptions." Party Politics .

Stevens, Daniel \& Susan Banducci. 2013. "One voter and two choices: the impact of electoral context on the 2011 UK referendum.” Electoral Studies 32:274284.

Takens, Janet, Jan Kleinnijenhuis, Anita Van Hoof \& Wouter Van Atteveldt. 2015. "Party Leaders in the Media and Voting Behavior: Priming Rather Than Learning or Projection.” Political Communication 32(2):249-267.

Tedin, Kent, Brandon Rottinghaus \& Harrell Rodgers. 2010. "When the president goes public.” Political Research Quarterly 20:1-14.

Tomz, Michael, Joshua A. Tucker \& Jason Wittenberg. 2002. “An Easy and Accurate Regression Model for Multiparty Electoral Data." Political Analysis 10:66-83.

Vavreck, Lynn. 2009. The Message Matters: The Economy and Presidential Campaigns. Princeton, N.J.: Princeton University Press.

Verba, Sidney, Kay Lehman Schlozman \& Henry E. Brady. 1995. Voice and Equality: Civic Voluntarism in American Politics. Cambridge: Harvard University Press. 
Whitford, Andrew B. \& Jeff Yates. 2009. Presidential Rhetoric and the Public Agenda: Constructing the War on Drugs. John Hopkins University Press.

Whitten, Guy D. \& Harvey D. Palmer. 1996. “Heightening Comparativists' Concern for Model Choice: Voting Behavior in Great Britain and the Netherlands." American Journal of Political Science 40(1):231-260.

Williams, Laron K. \& Guy D. Whitten. 2012. "But Wait, There's More! Maximizing Substantive Inferences from TSCS Models." The Journal of Politics 74:685-693.

Williams, Laron K., Katsunori Seki \& Guy D. Whitten. 2016. "You've Got Some Explaining To Do: The Influence of Economic Conditions and Spatial Compeition on Party Strategy." Political Science Research and Methods 4(1):47-63.

Williams, Laron K., Mary Stegmaier \& Marc Debus. forthcoming. "Relaxing the Constant Economic Vote Restriction: Economic Evaluations and Party Support in Germany.” Party Politics .

Zaller, John R. 1992. The Nature and Origins of Mass Opinion. New York: Cambridge University Press.

Zellner, Arnold. 1962. "An Efficient Method of Estimating Seemingly Unrelated Regressions and Tests for Aggregation Bias." Journal of the American Statistical Association 57:348-368. 
Figure 1: Salience of Economic and Social Problems and Evaluations of the National Economy
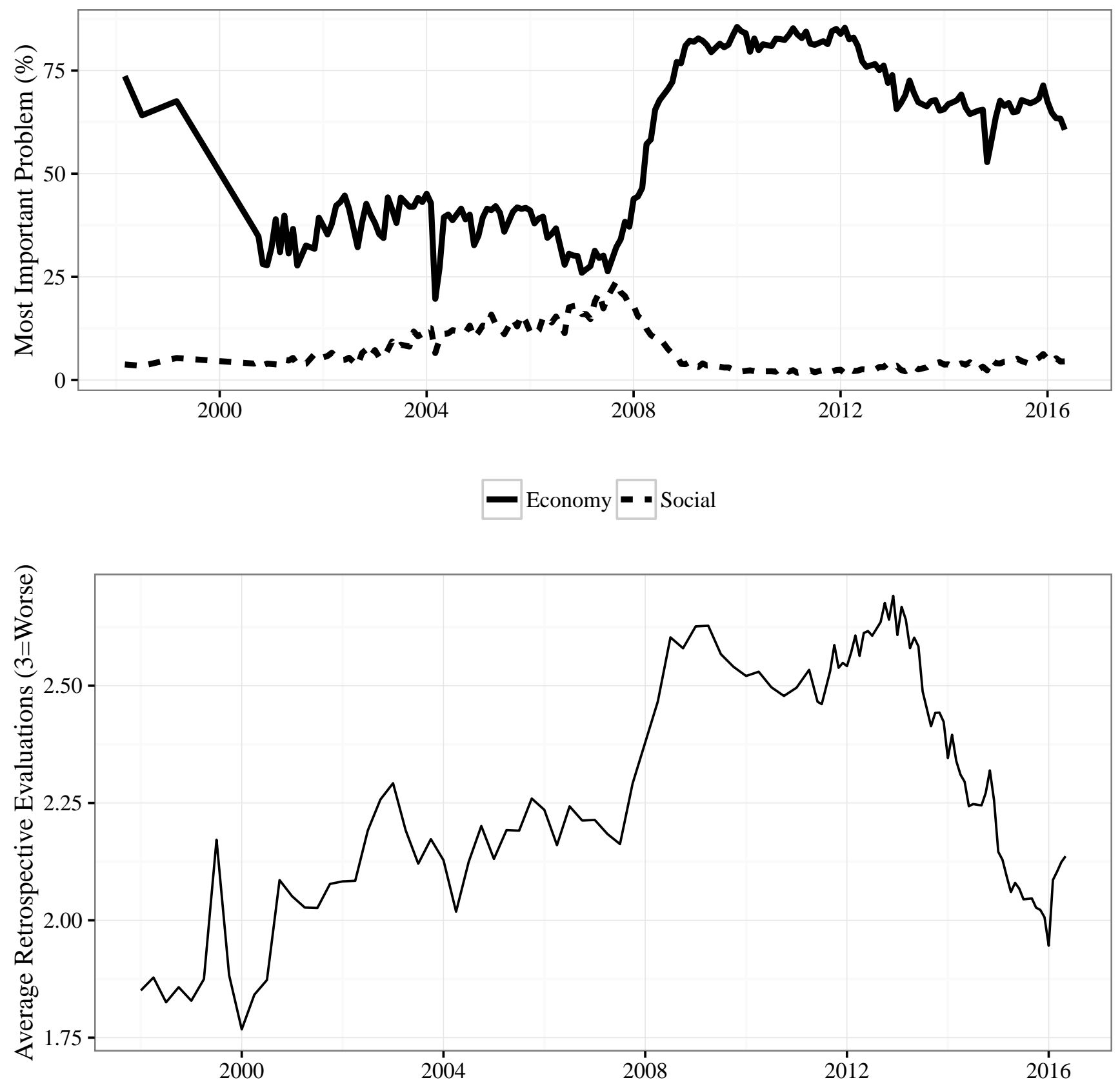

Note: Economic (social) salience is the percentage of respondents identifying economic (social) problems as the "most important problem facing Spain today". Economic evaluations is the average retrospective evaluation of the national economy over the last year, where $1=$ better, $2=$ stay the same and $3=$ worse. 
Figure 2: Vote Intention for PP and PSOE, 1998-2016

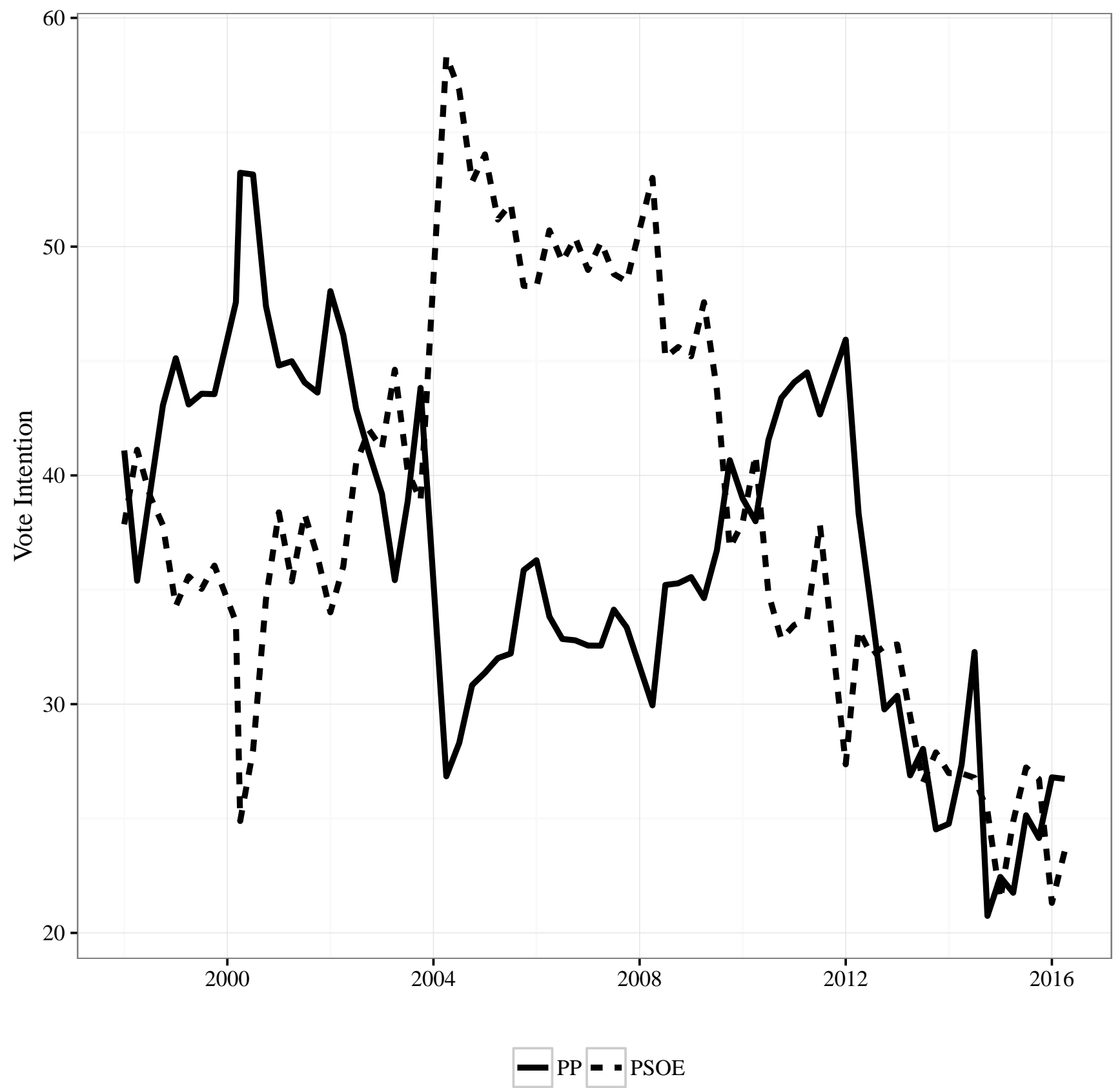


Figure 3: Dynamic Simulation of the Effects of Debates on Vote Intention (\%)

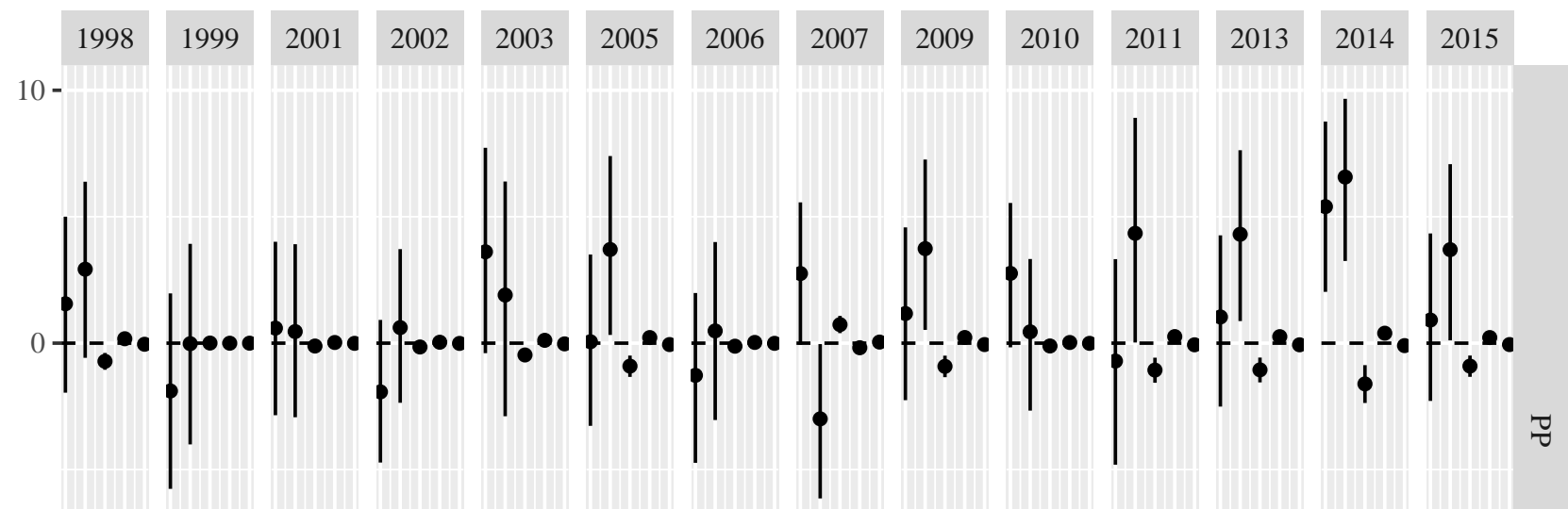

$-10-$

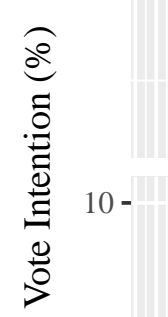

$-10-$

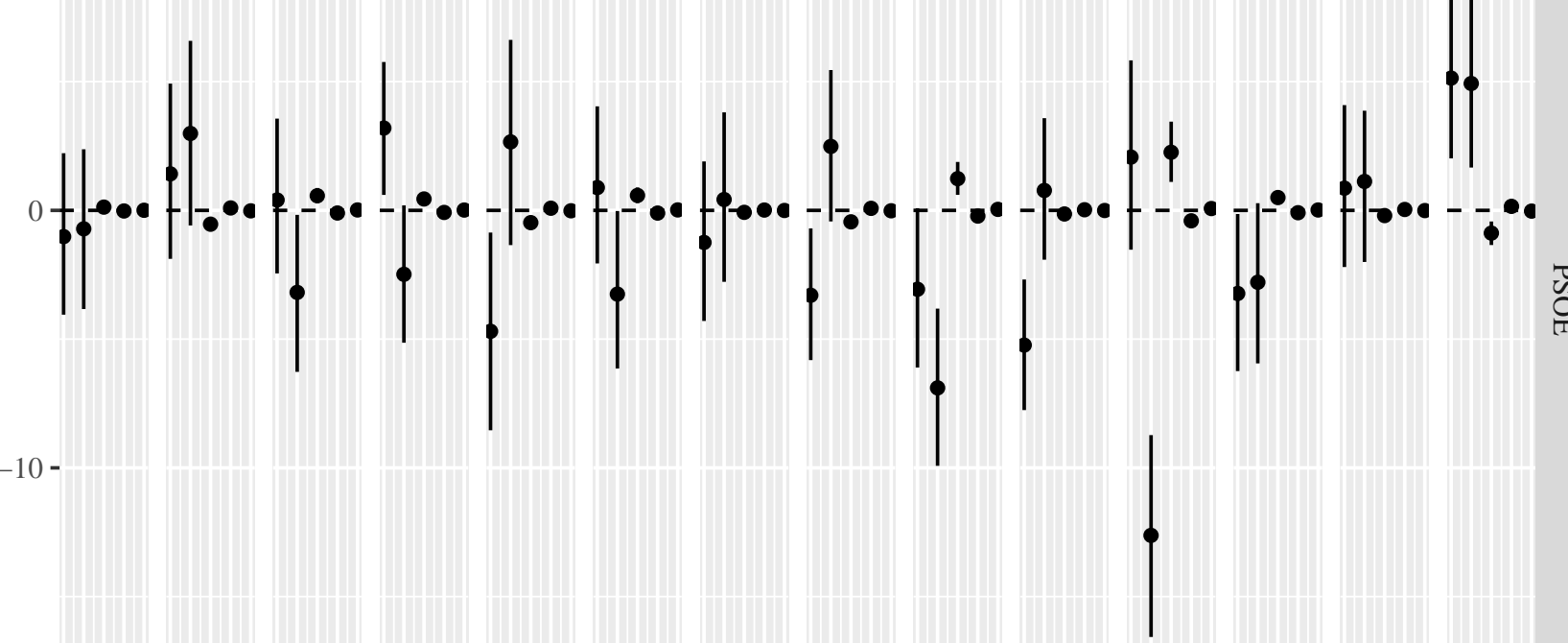

Note: Dots depict predicted changes to vote intention (with $90 \%$ confidence intervals) for the five periods following a debate at time $t=1$. The horizontal dashed line represents the null hypothesis of no effect. 
Table 1: Seemingly Unrelated Regression (SUR) Results for the Effects of Debates on Changes in Vote Intention

\begin{tabular}{|c|c|c|c|c|}
\hline & \multicolumn{2}{|c|}{$\mathbf{P P}$} & \multicolumn{2}{|c|}{ PSOE } \\
\hline & $\beta$ & S.E. & $\beta$ & S.E. \\
\hline$\Delta$ Vote $_{t-1}$ & $-0.25^{* * *}$ & 0.07 & $-0.18^{* * *}$ & 0.06 \\
\hline 1998 Debate $_{t}$ & 1.55 & 2.16 & -1.00 & 1.90 \\
\hline 1998 Debate $_{t-1}$ & 3.35 & 2.13 & -0.90 & 1.91 \\
\hline 1999 Debate $_{t}$ & -1.95 & 2.25 & 1.51 & 2.01 \\
\hline 1999 Debate $_{t-1}$ & -0.54 & 2.36 & 3.30 & 2.12 \\
\hline 2001 Debate $_{t}$ & 0.51 & 2.04 & 0.52 & 1.83 \\
\hline 2001 Debate $_{t-1}$ & 0.58 & 2.06 & $-3.11^{*}$ & 1.86 \\
\hline 2002 Debate $_{t}$ & -1.93 & 1.69 & $3.19^{* *}$ & 1.53 \\
\hline 2002 Debate $_{t-1}$ & 0.14 & 1.82 & -1.89 & 1.63 \\
\hline 2003 Debate $_{t}$ & 3.68 & 2.47 & $-4.73^{* *}$ & 2.22 \\
\hline 2003 Debate $_{t-1}$ & 2.78 & 2.77 & 1.82 & 2.49 \\
\hline 2005 Debate $_{t}$ & 0.08 & 2.04 & 0.89 & 1.85 \\
\hline 2005 Debate $_{t-1}$ & $3.55^{*}$ & 2.03 & $-3.00^{*}$ & 1.83 \\
\hline 2006 Debate $_{t}$ & -1.28 & 2.10 & -1.21 & 1.88 \\
\hline 2006 Debate $_{t-1}$ & -0.01 & 2.13 & 0.28 & 1.91 \\
\hline 2007 Debate $_{t}$ & 2.68 & 1.76 & $-3.23^{* *}$ & 1.58 \\
\hline 2007 Debate $_{t-1}$ & -2.43 & -1.90 & 1.93 & 1.70 \\
\hline 2009 Debate $_{t}$ & 1.09 & 2.12 & -3.01 & 1.92 \\
\hline 2009 Debate $_{t-1}$ & $3.98^{*}$ & 2.06 & $-7.51^{* * *}$ & 1.86 \\
\hline 2010 Debate $_{t}$ & $2.77^{*}$ & 1.69 & $-5.27^{* * *}$ & 1.52 \\
\hline 2010 Debate $_{t-1}$ & 1.09 & 1.85 & -0.14 & 1.68 \\
\hline 2011 Debate $_{t}$ & -0.77 & 2.49 & 2.01 & 2.24 \\
\hline 2011 Debate $_{t-1}$ & 4.11 & 2.66 & $-12.20^{* * *}$ & 2.40 \\
\hline 2013 Debate $_{t}$ & 1.13 & 2.11 & $-3.31^{*}$ & 1.88 \\
\hline 2013 Debate $_{t-1}$ & $4.51^{* *}$ & 2.07 & $-3.31^{*}$ & 1.87 \\
\hline 2014 Debate $_{t}$ & $5.33^{* * *}$ & 2.03 & 0.94 & 1.82 \\
\hline 2014 Debate $_{t-1}$ & $7.92^{* * *}$ & 2.06 & 1.28 & 1.83 \\
\hline 2015 Debate $_{t}$ & 0.92 & 2.12 & $5.20^{* * *}$ & 1.91 \\
\hline 2015 Debate $_{t-1}$ & $3.85^{*}$ & 2.16 & $5.77^{* * *}$ & 1.95 \\
\hline Madrid Bombings & $-17.75^{* * *}$ & 3.74 & $16.69^{* * *}$ & 3.38 \\
\hline Average Evaluations & 1.81 & 3.46 & -0.02 & 3.17 \\
\hline PP Government & 11.63 & 9.50 & 5.53 & 8.38 \\
\hline Evaluations $\times \mathrm{PP}$ & $-6.98^{*}$ & 4.07 & -0.68 & 3.57 \\
\hline Aznar I Trend & $0.08^{* *}$ & 0.04 & $-0.12^{* * *}$ & 0.04 \\
\hline Aznar II Trend & 0.05 & 0.05 & -0.04 & 0.05 \\
\hline Zapatero I Trend & -0.04 & 0.05 & $0.08^{*}$ & 0.04 \\
\hline Zapatero II Trend & -0.07 & 0.06 & $0.11^{*}$ & 0.05 \\
\hline Rajoy Trend & 0.04 & 0.03 & $-0.13^{* * *}$ & 0.03 \\
\hline Constant & -3.12 & 8.13 & -1.75 & 7.44 \\
\hline $\mathrm{N}$ & 68 & & 68 & \\
\hline $\mathrm{R}^{2}$ & 0.72 & & 0.81 & \\
\hline RMSE & 1.92 & & 1.74 & \\
\hline
\end{tabular}


Table 2: Long-Term Effects of the Covariates (Table 1 ) on Changes in Vote Intention

\begin{tabular}{|c|c|c|c|c|}
\hline & \multicolumn{2}{|r|}{ PP } & \multicolumn{2}{|c|}{ PSOE } \\
\hline & L.T.E. & 95\% C.I. & L.T.E. & 95\% C.I. \\
\hline 1998 Debate $_{t}$ & 3.94 & {$[-1.48,9.33]$} & -1.64 & {$[-6.47,3.40]$} \\
\hline 1999 Debate $_{t}$ & -1.86 & {$[-7.98,4.06]$} & 3.95 & {$[-1.62,9.30]$} \\
\hline 2001 Debate $_{t}$ & 0.97 & {$[-3.71,5.77]$} & -2.29 & {$[-6.63,2.02]$} \\
\hline 2002 Debate $_{t}$ & -1.42 & {$[-4.71,1.99]$} & 1.08 & {$[-2.07,4.33]$} \\
\hline 2003 Debate $_{t}$ & $5.15^{* *}$ & {$[0.84,9.01]$} & -2.44 & {$[-6.25,1.37]$} \\
\hline 2005 Debate $_{t}$ & 3.05 & {$[-1.68,7.80]$} & -1.85 & {$[-6.49,2.95]$} \\
\hline 2006 Debate $_{t}$ & -0.84 & {$[-6.01,4.18]$} & -0.91 & {$[-4.95,3.04]$} \\
\hline 2007 Debate $_{t}$ & 0.36 & {$[-3.39,4.04]$} & -1.19 & {$[-4.95,2.18]$} \\
\hline 2009 Debate $_{t}$ & $4.16^{*}$ & {$[-0.40,9.40]$} & $-8.93^{* * *}$ & {$[-13.72,-4.27]$} \\
\hline 2010 Debate $_{t}$ & $3.17^{*}$ & {$[-0.23,6.48]$} & $-4.61^{* *}$ & {$[-7.95,-1.26]$} \\
\hline 2011 Debate $_{t}$ & 2.79 & {$[-2.91,8.66]$} & $-8.65^{* * *}$ & {$[-15.27,-2.01]$} \\
\hline 2013 Debate $_{t}$ & $4.55^{*}$ & {$[-0.21,9.32]$} & $-5.66^{* *}$ & {$[-10.40,-1.30]$} \\
\hline 2014 Debate $_{t}$ & $10.74^{* * *}$ & {$[6.07,15.70]$} & 1.81 & {$[-2.67,6.20]$} \\
\hline 2015 Debate $_{t}$ & 3.97 & {$[-0.36,8.01]$} & $9.35^{* * *}$ & {$[4.13,14.43]$} \\
\hline Madrid Bombings & $-14.33^{* * *}$ & {$[-19.66,-9.27]$} & $14.19^{* * *}$ & {$[8.43,20.58]$} \\
\hline \multicolumn{5}{|l|}{ Average Evaluations } \\
\hline PP in Government & $-4.17^{* * *}$ & {$[-7.00,-1.29]$} & -0.60 & {$[-3.40,1.99]$} \\
\hline PSOE in Government & 1.42 & {$[-3.92,6.52]$} & 0.02 & {$[-5.03,5.35]$} \\
\hline Aznar I Trend & $0.07^{*}$ & {$[-0.01,0.13]$} & $-0.10^{* * *}$ & {$[-0.17,-0.04]$} \\
\hline Aznar II Trend & 0.04 & {$[-0.05,0.13]$} & -0.03 & {$[-0.11,0.05]$} \\
\hline Zapatero I Trend & -0.04 & {$[-0.12,0.03]$} & $0.07^{*}$ & {$[0.00,0.15]$} \\
\hline Zapatero II Trend & -0.05 & {$[-0.16,0.04]$} & $0.09^{*}$ & {$[-0.01,0.18]$} \\
\hline Rajoy Trend & 0.03 & {$[-0.02,0.08]$} & $-0.11^{* * *}$ & {$[-0.16,-0.06]$} \\
\hline
\end{tabular}

Note: ${ }^{*}$ : p-value $<0.1,{ }^{* *}:$ p-value $<0.05,{ }^{* * *}$ : p-value $<0.01$ 